DOI https://doi.org/10.18551/rjoas.2017-05.37

\title{
THE IMPACT OF THE POLICY ON THE IMPORTED BEEF FROM AUSTRALIA AND THE PRODUCTION OF DOMESTIC BEEF
}

\author{
Maruli Pahantus* \\ Faculty of Animal Science, University of Jambi, Indonesia \\ Minha Amruzi, Adriani Dessy \\ Faculty of Agriculture, University of Sriwijaya, Indonesia
}

\author{
Susetyo Didik \\ Faculty of Economic and Business, University of Sriwijaya, Indonesia \\ *E-mail: pahantusmarulihutabarat@yahoo.com
}

\begin{abstract}
The objective of this study was to analyze the impact of the policy on the imported beef from Australia and the production of domestic beef. This study was conducted in Indonesia. The type of data used in this study was time series data of the period of 1990 to 2014 . The data of the prices were obtained from the Ministry of Trade and the FAO and the Ministry of Agriculture. For the prices of the imported beef from Australian, the data were obtained from Australian authorities (Australian Bureau Statistic, Meat Livestock Association and Australian Bureau of Agricultural and Resource Economics and Sciences). The data analysis used was trend analysis. The volume of beef imports from Australia has increased enormously over the last 25 years with an average increase of $40.19 \%$ per year. The policy affecting beef imports from Australia is the Indonesian Act No. 18 of the Year 2009 on Animal Husbandry and Animal Health with the country-based principles.
\end{abstract}

\section{KEY WORDS}

Policy, import, production, beef.

Initially, the import system of beef and live cattle used was a country base system. But then the government then chose the zone base import system. This system is a system that is the continuation of the previous one in harmony with the increasing availability of meat supply in the country. With this system, the government will direct the imports only to certain zones of the country that have not reached their beef sufficiency. The most difficult zones to meet are Jabodetabek and parts of North Sumatra. Therefore, in the first quarter, the government imported 100,000 head of feeder cattle to meet the needs in these two locations. One of the main beef-importing countries to Indonesia in the era of country base was Australia. Australia was chosen because of the proximity and excess supply of meat it has, in addition to low production costs and geographical proximity that minimizes shipping costs. Eighty seven percent $(87 \%)$ of live cattle exported from the Northern Australia is directed to the Indonesian market (Martin et al., 2012). In January 2015, Australia exported US \$ 327 million worth of beef to Indonesia, $13 \%$ or US $\$ 42$ million was in the form of secondary cut and edible offal.

In the era of zone base, Indonesia is free to import meat from various countries. In line with this, there an idea to replace Australian beef with Indian buffalo meat. Later, in order to prepare for self-sufficiency in cattle, private importers are required to import $20 \%$ of the total imports of beef feeder cattle and broodstock, while the cooperative farmers are required to import $10 \%$ only. The Ministry of Trade will oversee the private sectors, while the Ministry of Cooperatives and SMEs will oversee the farmer cooperatives. It is expected that with the import of feeder cattle and broodstock, the farmers and the private sector are encouraged to breed their own cattle rather than importing from abroad. 
Indonesia is the largest market for live cattle from the Northern Australia. The data of 2011 showed that $87 \%$ of Australia's exports of live cattle were directed to Indonesia. Even so, live cattle are account for only $8 \%$ of the total Australian cattle exports. The majority of Australian cattle exports is in the frozen form (92\%). Indonesia has very little portion for frozen beef. Cumulatively, Indonesia is only an export market of $8.03 \%$ of Australian cattle products, comprising $5.03 \%$ live cattle and $3.00 \%$ frozen meat. From the Indonesian side, this means that the imported meat from Australia consists of $62.6 \%$ of live cattle and $37.4 \%$ of frozen meat (Martin et al., 2012).

What are Indonesian government efforts to achieve self-sufficiency in cattle in Indonesia. Tenrissana et al (2016) stated that until 2014 Indonesia had made four attempts to issue the policy of self-sufficiency in cattle in Indonesia, and all of them failed. What then ensures that current policies will succeed in achieving self-sufficiency in cattle? Tenrissana et al (2016) suggested that there should be an evaluation of the policy of meat self-sufficiency in Indonesia to anticipate the problems and find the recommendations at the level of farmers and livestock entrepreneurs.

\section{METHODS OF RESEARCH}

This study was conducted in Indonesia. The location of the study was deliberately determined on the basis that the needs of Indonesian meat are always unmet, so importing is required. Beef imports to Indonesia are mainly from Australia. The type of data used in this study is time series data of the period of 1990 to 2014. The data on prices are obtained from the Ministry of Trade and FAO and the Ministry of Agriculture. The data on local cattle productivity, the quantity of chicken and fish are obtained from the Ministry of Agriculture. The data on the previous and current imports and related industrial developments are obtained from the Ministry of Trade. The data on per capita income are obtained from BPS. The data on the proportion of previous imports are obtained from Australian authorities (Australian Bureau Statistic, Meat Livestock Association, and Australian Bureau of Agricultural and Resource Economics and Sciences). The data are analyzed by means of trend analysis.

\section{RESULTS AND DISCUSSION}

Imported Beef from Australia. The volume of beef imports from Australia has increased enormously over the last 25 years (Figure 1). It is proven by the fact that the volume of beef imports from Australia in 1990 was $391.771 \mathrm{~kg}$ which increased very high to become $58,111,173 \mathrm{~kg}$ in 2014 , or an average increase of $40.19 \%$ per year. On the one hand, the volume of the imports of beef from all countries increased considerably during the same period, namely in 1990 from 1,422,454 kg to become $67,908,200 \mathrm{~kg}$ in 2014 , or an average increase of $28.85 \%$ per year.

According to Tseuoa (2011), the policy of importing permit of feeder cattle and beef issued by the government in the 1980s was originally intended to provide cheap meat, so that the consumption of meat in the community would increase. However, in 2012 the proportion of the imported beef reached 369,693 tons of the national beef need, thus it alarmed food sovereignty and food security.

The share volume of beef import from Australia against the volume of beef imports from all other countries in the last 25 years tends to increase, namely $77.85 \%$ in 2014 which increased as compared to $27.54 \%$ in 1990 . On the average the share volume of the beef imports from Australia dominates (55.25\% per year) during the period of 1990-2014 against the beef imports from all other countries.

Prices of Domestic and Australian Beef. The price of domestic beef for 25 years, namely the period of 1990-2014 fluctuated with a tendency to increase from 2,686 US \$ per $\mathrm{kg}$ in 1990 to 8,373 US \$ per $\mathrm{kg}$ or an average growth of $7.67 \%$ per year. The average growth rate of domestic beef prices is much higher than the growth rate of Australian beef prices $(1.80 \%$ per year) and the growth of beef price of the World (1.61\% per year) in the 
same period (Figure 2). According to the Ministry of Agriculture of the Republic of Indonesia (2015), the current increase in beef prices is the result of an imbalance between the production quotas and the high public demand for beef. There are a number of constraints of cattle distribution / transportation from the production centers to consumers, both in terms of inter-island vessel transportation and land transportation which trigger increases in beef prices. Consequently Indonesia must import beef.

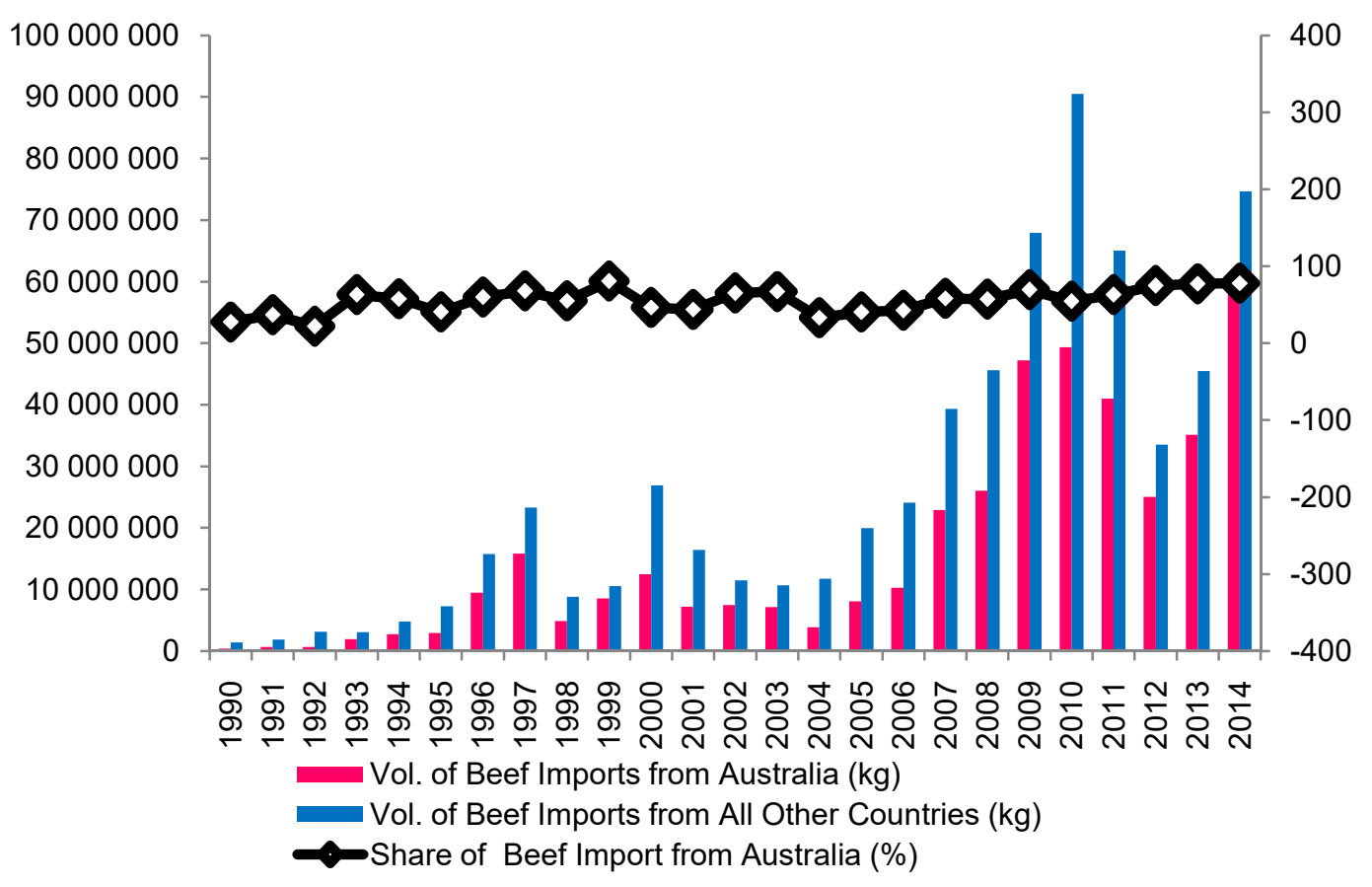

Figure 1 - The Development of the Volume and Share of Beef Import from Australia and All Other Countries, 1990-2014

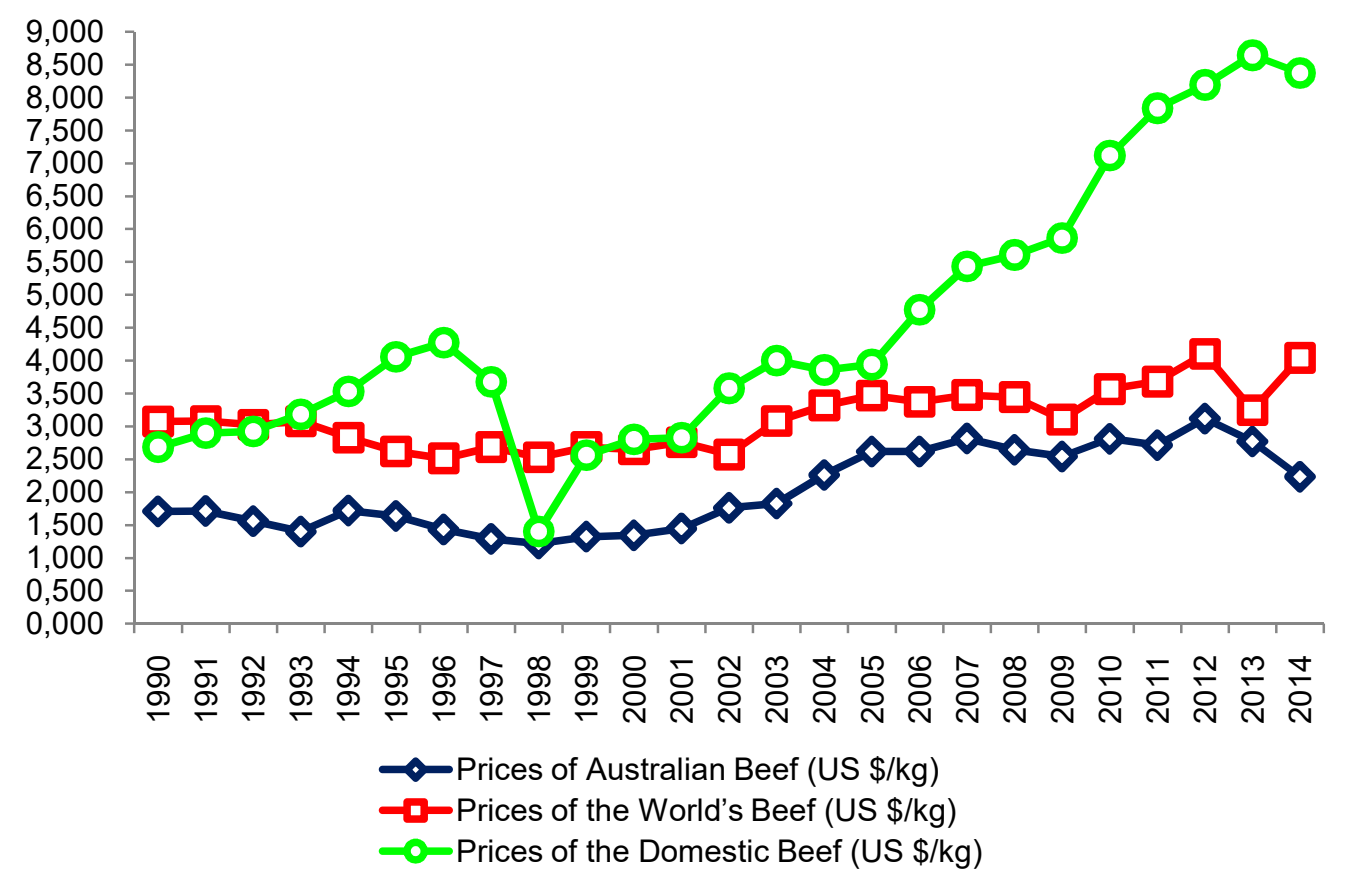

Figure 2 - The Development of the Australian, the World's and the Domestic Beef Prices, 1990-2014 (US \$ / kg) 
The development of Australian beef prices during the period of 1990-2014 relatively less fluctuating with the tendency to increase from 1,708 US \$ per kg in 1990 to 2,235 US \$ per kg or on average only grows at $1.80 \%$ per year, as shown in Figure 2. Compared to the price of the world's beef, the price of Australian beef for 25 years has been always lower, i.e the average difference (gap) of 1,088 US \$ per kg per year. Similarly, when compared to the price of the domestic beef, Australian beef is also always lower with an average of difference (gap) of 2.605 US \$ per kg per year.

Domestic and Australian Beef Production. The development of the domestic beef production in the same period (1990-2014) fluctuated with an increasing trend of $259,200,000$ per ton in 1990 to $545,621,000$ per ton or on average growth of only $3.80 \%$ per year. The development of Australian beef production during the period 1990-2013 as shown in Figure 3 was relatively stable with an increasing trend of $1,697,883$ tons in 1990 to $2,480,458$ tons in 2013 or an average growth of only $1.73 \%$ per year. The growth rate of Australian beef production during the period 1990-2013 was lower than the growth rate of the domestic beef production in the same period $(3.80 \%$ per year). However, the growth rate of the Australian beef production was higher than the growth rate of the world's beef production in the period of $1980-2015$ (data source: USDA) that is only $0.93 \%$.

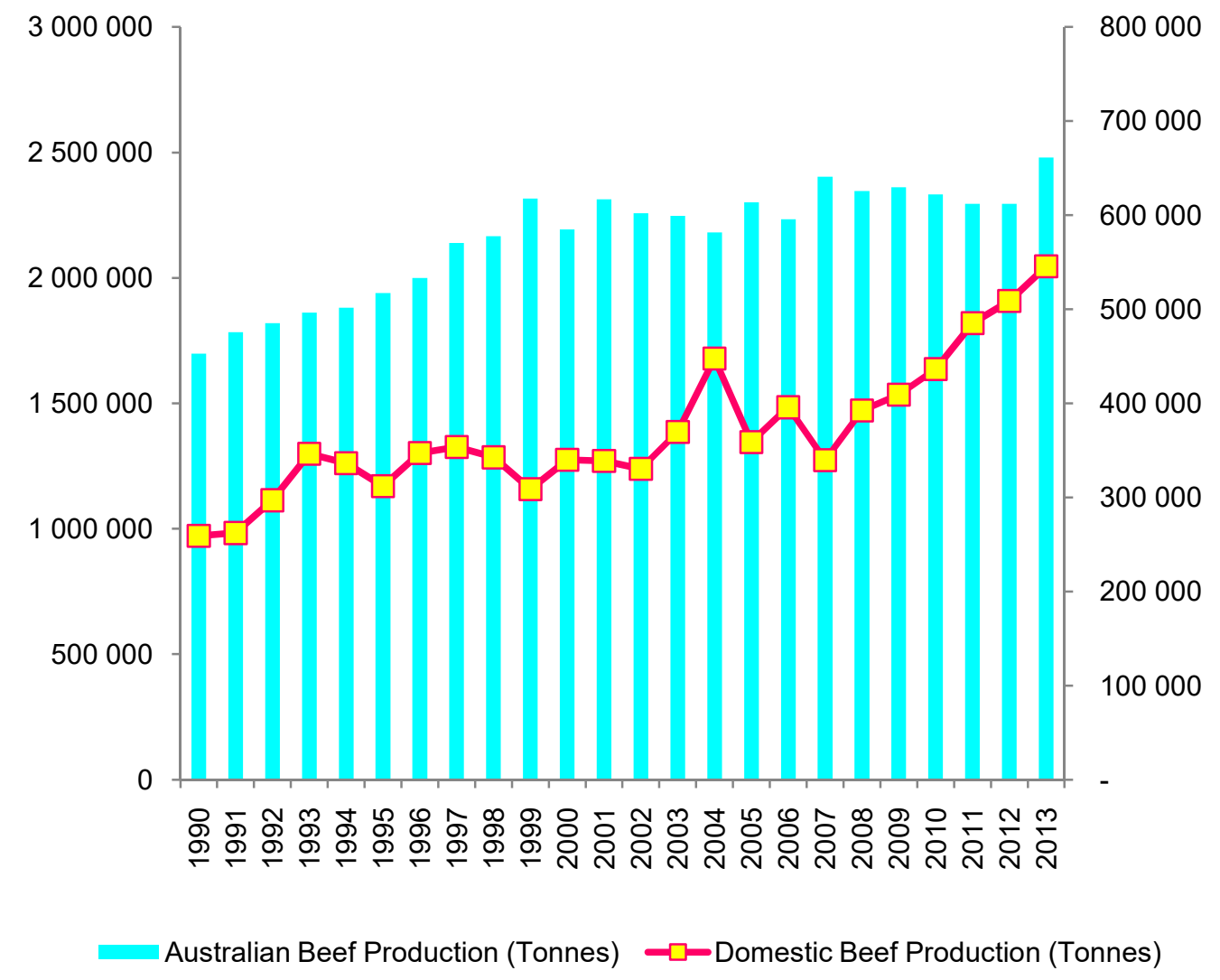

Figure 3 - The Development of Australian and Domestic Beef Production In the Period of 1990-2013 (tones)

In 2015 (USDA's Data), Australia's beef production was 2,275,000 tons. It contributed only $3.89 \%$ of the world's beef production. The largest contribution to the world's beef production was from the following countries: the United States $(19.53 \%)$, Brazil $(16.09 \%)$, European Union (12.88\%) and China (11.35\%) and India $(6.50 \%)$. While the development of the domestic beef production in the same period $(1990-2014)$ fluctuated with the increasing trend, namely from $259,200,000$ per ton in 1990 to $545,621,000$ per ton or on average only grew by $3.80 \%$ per year. 


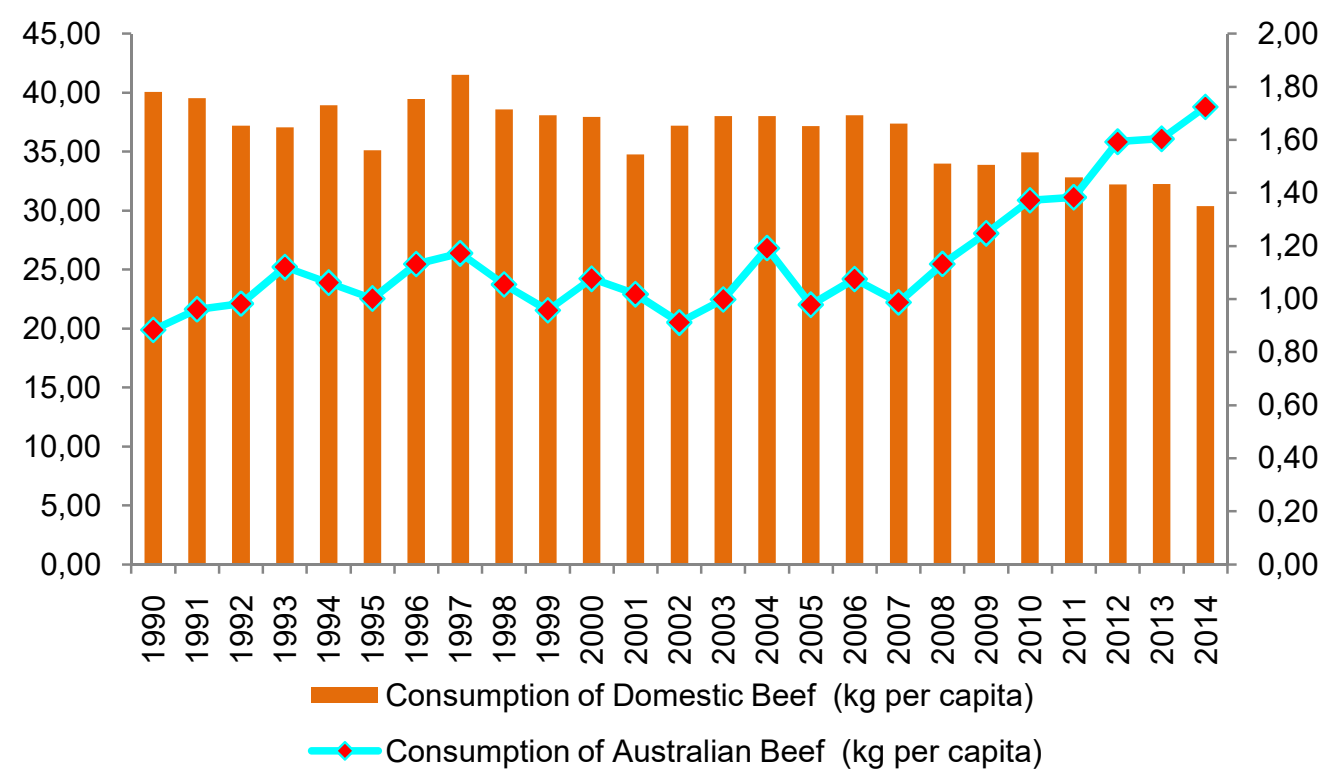

Figure 4 - The Development of the Per Capita Consumption of the Domestic and Australian Beef in the Period of 1990-2014 (Kg)

Consumption of Domestic Beef. The consumption of the domestic beef per capita increased substantially over the last 25 years (Figure 4). It is proven by the fact that the consumption of domestic beef in 1990 was only $0.88 \mathrm{~kg} /$ capita, while the consumption of domestic beef in 2014 was $1.72 \mathrm{~kg} /$ capita, which means that there was a very high increase by an average of $3.32 \%$ per year. Interestingly, Figure 4 presents an interesting fact that the consumption of Australian beef per capita during the period of 1990-2014 indicated a downward trend from $40.06 \mathrm{~kg} /$ capita / year in 1990 to $30.38 \mathrm{~kg} /$ capita / year in 2014 or an average decrease of $1.01 \%$ per year. The lowest per capita consumption of Australian beef occurred in 2014 at $30.38 \mathrm{~kg}$ / capita, while the highest per capita consumption of Australian beef occurred in 1997 at $41.50 \mathrm{~kg} /$ capita. In addition, the lowest growth rate of Australian beef consumption occurred in 1995 , namely $-9.78 \%$ of that of the previous year, while the highest occurred in 1996, namely $12.34 \%$ of that of the previous year.

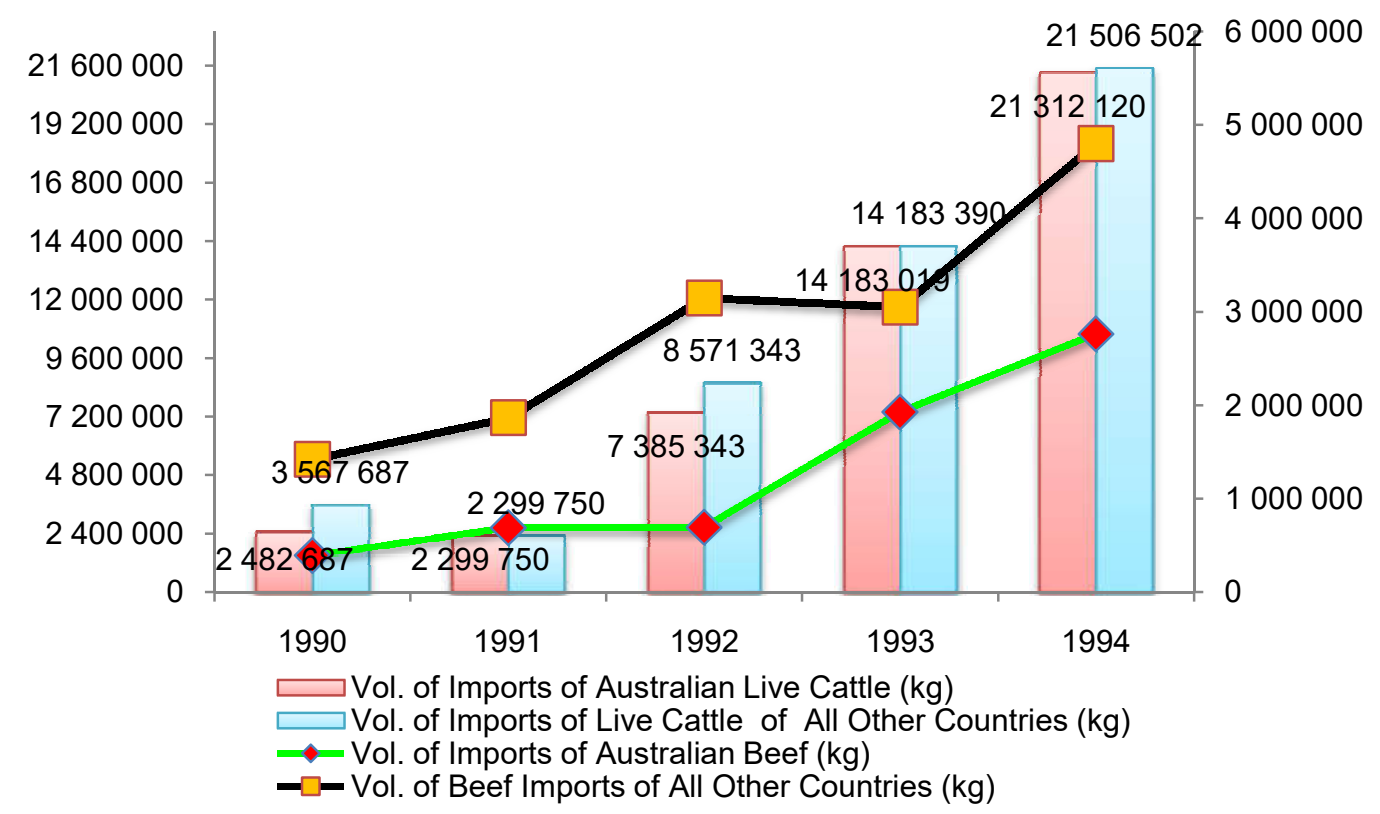

Figure 5 - The Development of Cattle Import from Australia and All Other Countries with the Existence of the Policy of Cattle Export Cessation 
The Impact of the Policy to stop export of cattle and buffalo to Singapore and Hong Kong in 1979. In the period of 1970-1979 Indonesia were a cattle and buffalo exporting country, with destination countries, among others, Singapore and Hong Kong. Some of the export livestock source areas are Aceh Province, Bali Province, West Nusa Tenggara (NTB) Province and East Nusa Tenggara (NTT) Province. However, on the grounds of the increasing domestic demand, since 1979 the government took a policy to stop the exports of cattle and buffalo (Ditjennak, 1990). 'With the policy to stop the exports of cattle and buffalo in 1979, the import of cattle from Australia from 1990-1994 continued rising.

Figure 5 shows the development of live cattle imports from Australia and the rest of the country with the policy of cessation of export of cattle and buffalo in 1979 with destination countries such as Singapore and Hong Kong has encouraged the development of Australian cattle imports relative to the development of cattle imports from all other countries.

The Impact of the Policy May Package of 1995. Under the policy of May Package 1995, the government issued a deregulation package of five parts: additional tariff and entry fees, import trading system, capital investment, licensing, business restructuring, and the export entrepot of the manufacturers and bonded areas. In 1995 through the May Package, the government followed the commitments of international trade agreements by opening itself to imported agricultural products and commodities. The concrete steps taken by the government were reducing the tariff on beef cattle products from $10 \%$ to $5 \%$, and lowering the import tariff of brood-stock cattle and feeder cattle from $5 \%$ to $0 \%$.

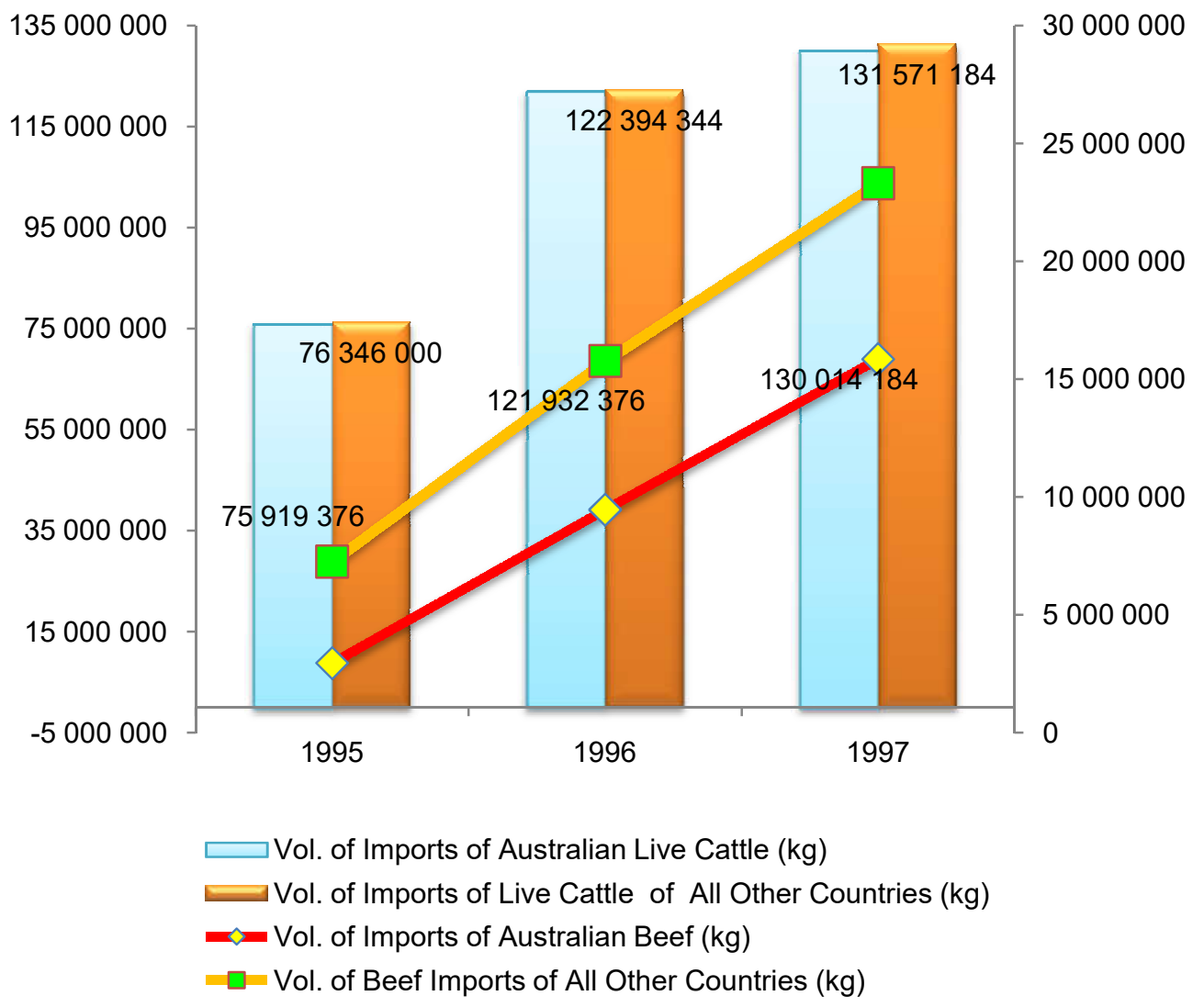

Figure 6 - The Development of Cattle Import from Australia and All Other Countries with the Existence of the Policy of May 1995 Package

The data in Figure 6 show that the policy of May 1995 Package has encouraged the increase of cattle imports from both Australia and all other countries, and the increase in cattle imports from Australia is much faster than the increase in cattle imports from all other countries. 


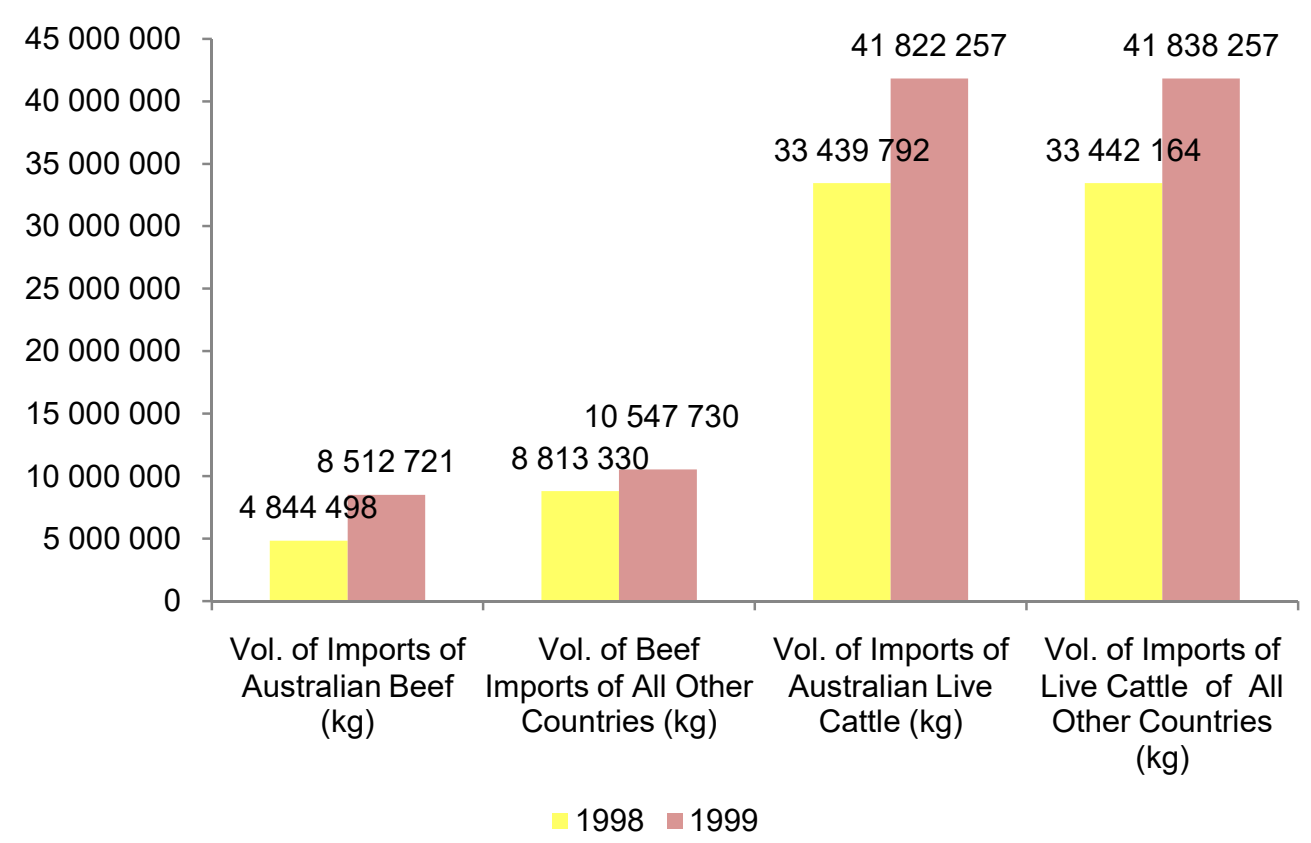

Figure 7 - The Development of Beef Import from Australia and All Other Countries with the Existence of the Presidential Instruction (Inpres) no. 2 of the Year 1998

The Impact of The Instruction of the President of the Republic of Indonesia Number 2 of the Year 1998 Concerning Trade Between Provinces and Regencies / Islands. The policy in the form of the Presidential Instruction of the Republic of Indonesia No. 2/1998 on the Trade Between Province and Regency / Islands arises from the insistence and pressure by IMF (International Monetary Fund) to eliminate all trade barriers occurring in Indonesian territory. The Instruction of the President of the Republic of Indonesia Number 2 of the Year 1998 has an impact on the increase in beef imports from Australia and all other countries of the period of 1998-1999 (Figure 7). This policy has stimulated an increase in beef imports from Australia much faster than the increase in beef imports from all other countries.

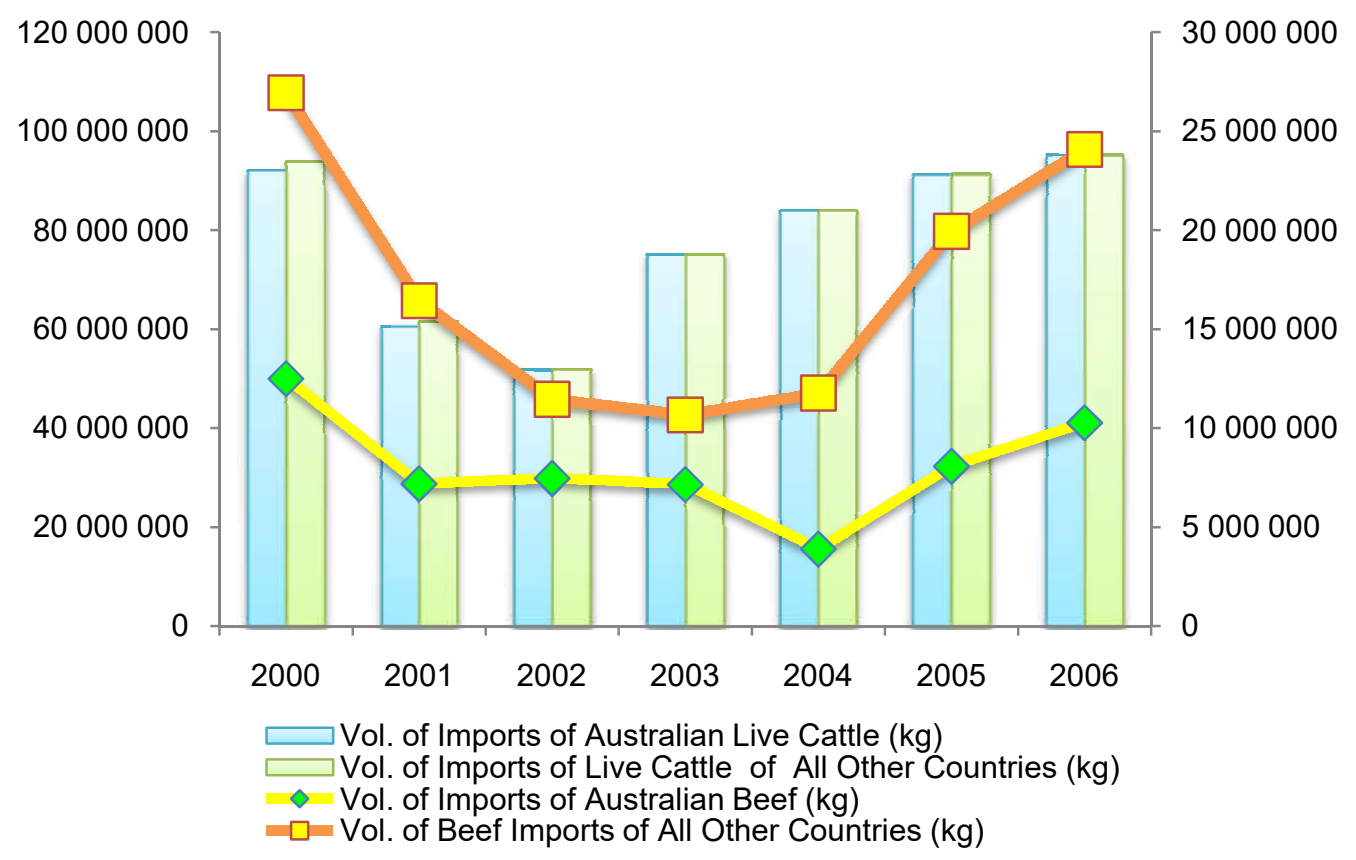

Figure 8 - The Development of Cattle Import from Australia and All Other Countries with the Existence of the Cattle Sufficiency Program of 2005 
The Impact of the Beef Sufficiency Program of 2005. The 2005 Beef Sufficiency Program is listed in the Strategic Plan of the Directorate General of Livestock in the period of 2005-2010. The 2005 Beef Sufficiency Program has an impact on imported cattle from Australia during 2000-2006 in the form of the decrease in cattle imports from Auatralia, namely from 12,502,770 kg in 2000 down in 2006 to 10,271,066 kg (Figure 8). This program had a negative impact on the imports of cattle from all countries during 2000-2006. The impact was indicated by the decrease of the import of cattle from all countries from $26,937,124 \mathrm{~kg}$ in 2000 to $24,078,542 \mathrm{~kg}$ in 2006 , or an average of $17,326,550 \mathrm{~kg}$ per year

The Impact of The Regulation of the Minister of Agriculture Number: 59/Permentan/HK. 060/8/2007 about the Guidelines for Accelerating the Achievement of Self-Sufficiency of Beef. The Policy of Accelerating the Achievement of Self-Sufficiency of Beef (P2A2SB) to ensure the success of farmer empowerment efforts, the strict supervision must be conducted on the export/import of livestock and livestock products. The results of the calculation indicate that the imposition of $25-40 \%$ import duties can still be considered for the farmers' empowerment. The policy of P2A2SB affects the increase of beef import from Australia and all other countries in the period of 2007-2009. The rate of beef imports from Australia increased by an average of $47.46 \%$ per year. The average increase in beef imports from Australia is greater than the average increase in beef imports from all other countries (32.24\%).

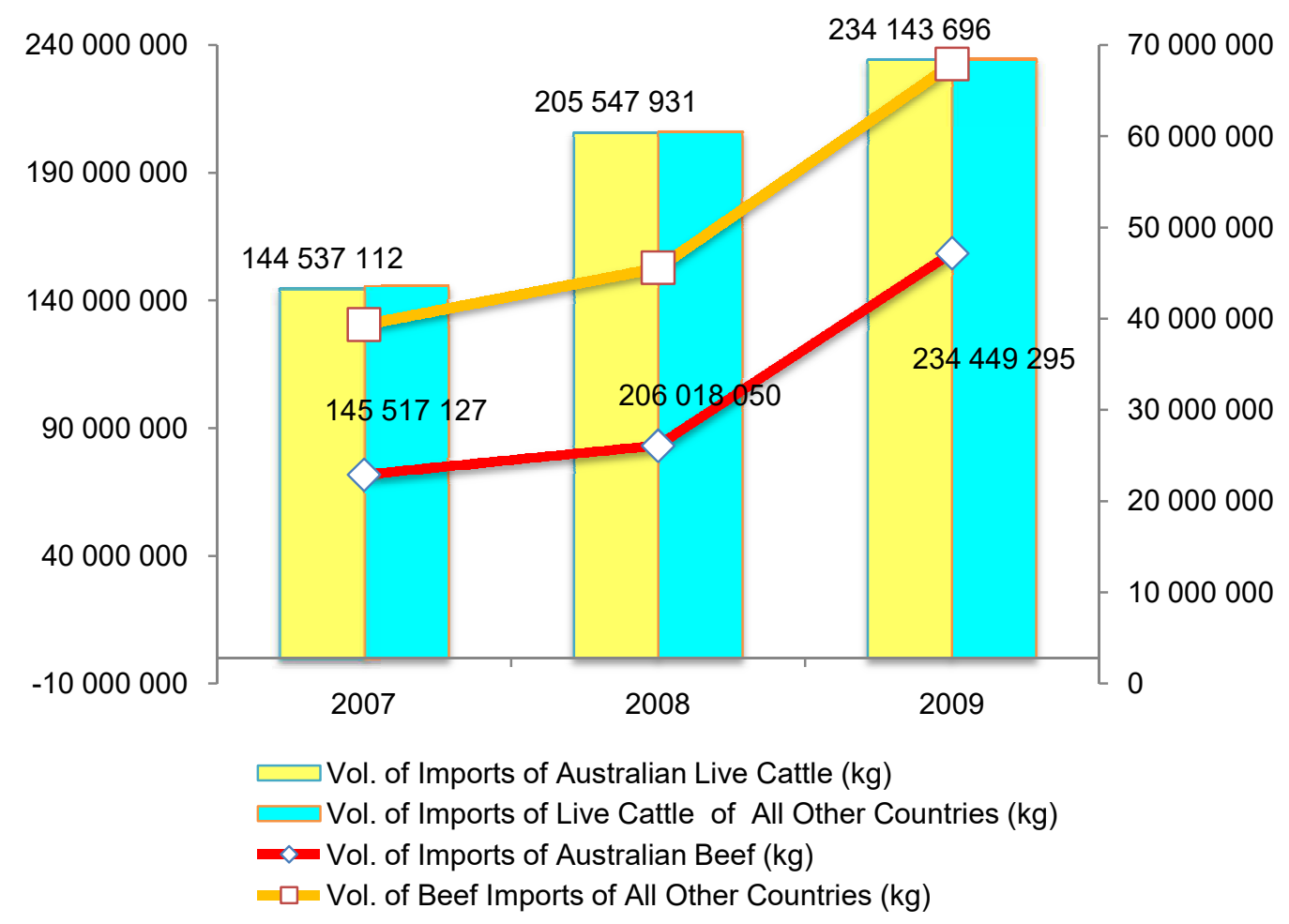

Figure 9 - The Development of Cattle Import from Australia and All Other Countries with the Existence of the Policy of Accelerating the Achievement of Self-Sufficiency in Beef (P2A2SB)

The Impact of The Regulation of the Minister of Agriculture Number: 19/Permentan/ OT.140 / 2/2010 On the General Guidelines of the Beef Self-Sufficiency Program in 2014. The polici of the Beef Self-Sufficiency Program in 2014 (BSSP) had the objective of reducing cattle and meat imports to only $10 \%$ of the community's consumption needs. The negative impact of the policy (decrease) of BSSP of 2014 on beef import from Australia also applies to the imports of beef from all other countries during 2010-2011. The data in Figure 10 indicate that the policy of the Self-Sufficiency Program of 2014 inhibits the import of beef from Australia and imports of beef from all other countries. The rate of beef imports from Australia 
declined at an average of $-16.93 \%$ per year. The average decline in import rate of beef from Australia is lower than the average decline in import rate of beef from all other countries ($28.16 \%$ per year).

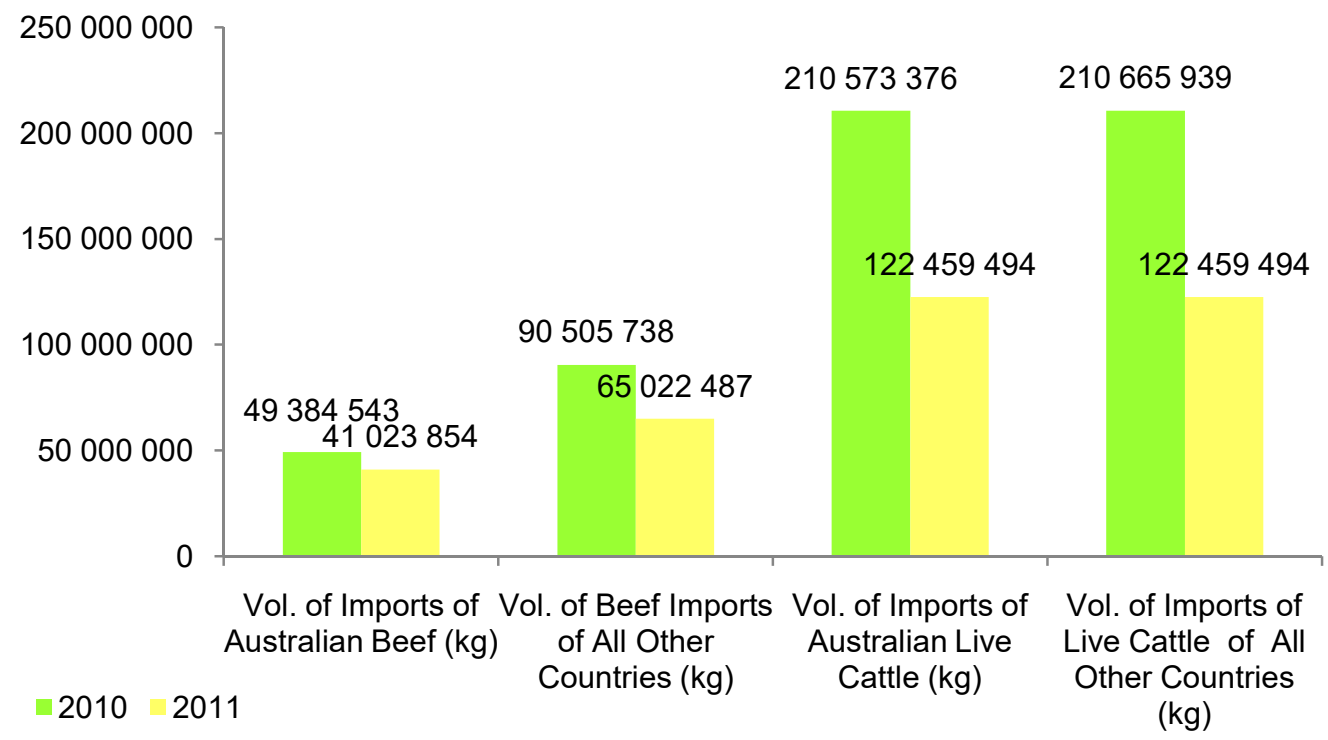

Figure 10 - The Development of Beef Import from Australia and All Other Countries with the Existence of BSSP 2014

The Impact of The Regulation of the Minister of Agriculture Number: 50/Permentan /OT.140/9/2011 On the Recommendation of Approval of Import of Carcass, Meat, Offal, and/or Processed Items into Indonesia and the Regulation of the Minister of Trade No. 24/MDag/Per/9/2011 About the Provisions of Import and Export of Animals and Animal Products. These regulations impeded the import of Australian beef and beef imports from all other countries. However, on the average the number of beef imports from Australia from 20112012 was still below the average number of beef imports from all other countries at $49,264,463 \mathrm{~kg}$ per year (Figure 11). However, the rate of beef imports from Australia declined at an average of $-38.91 \%$ per year, lower than the average decline in import rate of beef from all other countries (-28.16\% per year).

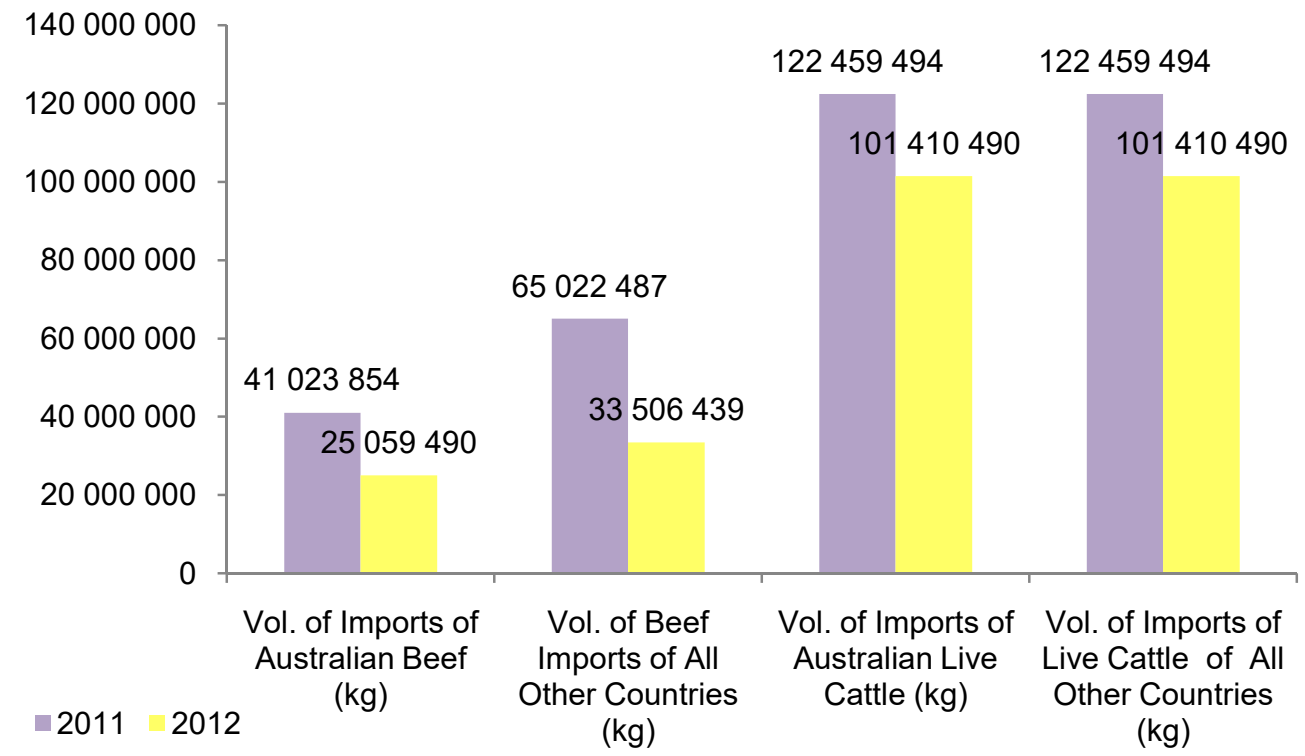

Figure 11 - The Development of Cattle Imports from Australia with the Existence of the Policy of the Minister of Agriculture No. 50 of 2011 and the Regulation of the Minister of Trade \#24 of the 2011 
It is interesting that in this period the import of live cattle from Australia was exactly the same as the import of live cattle from all other countries. This means that the government policy in the form of the Regulation of the Minister of Agriculture Number: 50 / Permentan / OT.140 / 9/2011 and the Regulation of the Minister of Trade No. 24 / M-Dag / Per / 9/2011 had caused no other country than Australia to export live cattle to Indonesia.

The Impact of the Regulation of the Minister of Trade No. 46/M-Dag/Per/8/2013 on the Provisions on the Import and Export of Animals and Animal Products. The data in Figure 12 show that the Regulation of the Minister of Trade of the Republic of Indonesia No. 46 / MDag / Per / 8/2013 encouraged the import of beef from Australia and the imports of beef from all other countries.

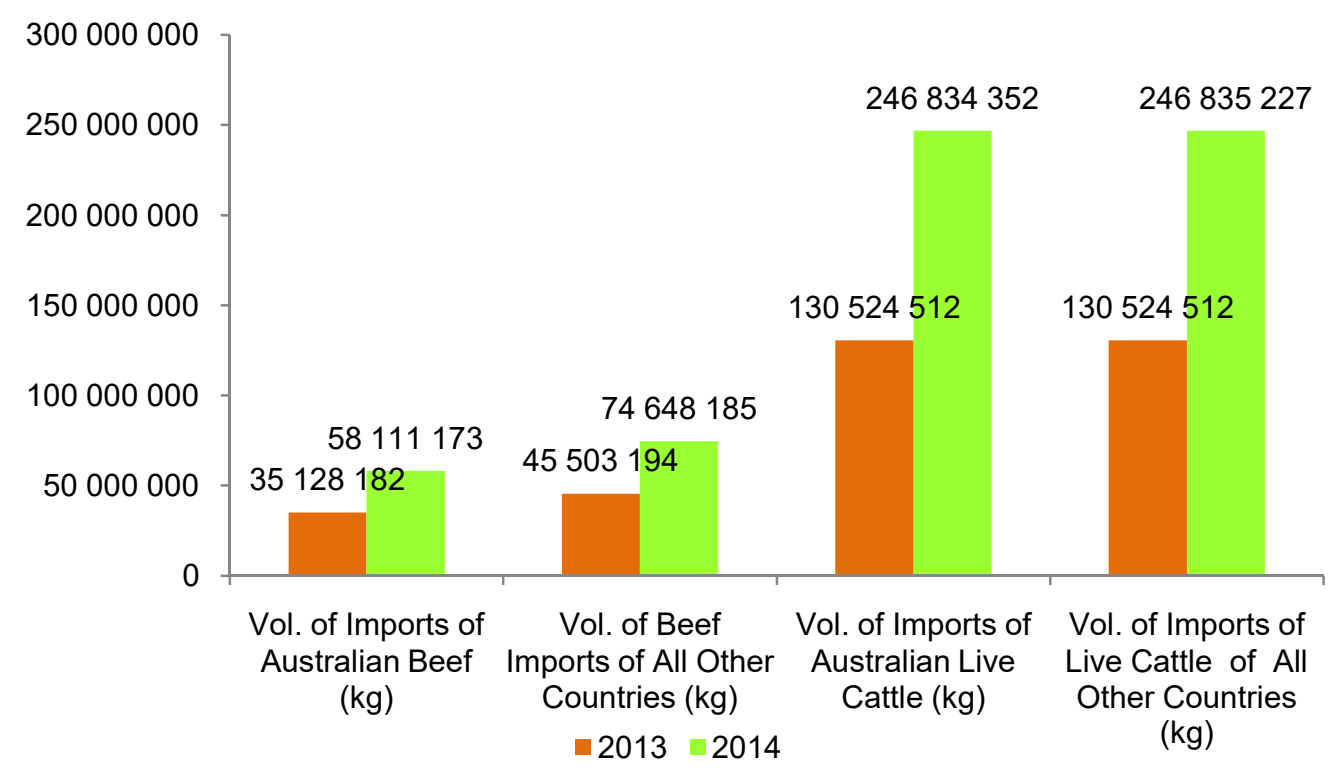

Figure 12 - The Development of Beef Import from Australia and All Other Countries with the Existence of the Policy on Trade Ministerial Regulation No. 699 of the year 2013 and Minister of Trade Regulation No. 46 of 2013

In 2013 the Regulation of the Minister of Trade of the Republic of Indonesia No. 46 / MDag / Per / 8/2013 Regarding Provisions on the Import and Export of Animals and Animal Products was implemented. The regulation caused an increase in beef imports from Australia during the period of 2011-2012. The data in Figure 12 show that the import of beef from Australia in 2013 as much as $35,128,182 \mathrm{~kg}$ rose to $58.111 .173 \mathrm{~kg}$ in 2014 with an average of $46.619 .678 \mathrm{~kg}$ per year. However, on the average the number of beef imports from Australia during 2011-2012 was still below the average number of beef imports from all other countries, namely $60,075,690 \mathrm{~kg}$ per year. However, the rate of beef imports from Australia has increased by an average of $65.43 \%$ per year, relatively the same as the average increase in import rate of beef from all other countries (64.05\% per year).

The Impact of Indonesian Act Number 18 of the Year 2009 about Animal Husbandry and Animal Health. The policy affecting the import of beef from Australia and the import of live cattle from Australia is the Indonesian Act No. 18 of 2009 on the Livestock and Animal Health. The policy of import of beef and live cattle applied by Indonesia is the principle of country based. The country-based principle restricts Indonesia to be able to import beef and live cattle only from countries that have met health requirements, such as free of mouth and nail disease (MND). The countries that have been declared free of MND are Australia, New Zealand, USA, Canada, and Indonesia.

The imports of beef from Australia before the Act was valid (1990-2008) was an average of 8,082,171 kg per year. After the law was in force (2009-2014) the import of beef from Australia jumped very high at an average of $42,649,507 \mathrm{~kg}$ per year. Similarly, the 
import of live cattle from Australia before this Act was implemented was an average of $71,578,562 \mathrm{~kg}$ per year. After this Act was implemented, the import of live cattle from Australia jumped very high, on the average, as much as $119.992 .788 \mathrm{~kg}$ per year.

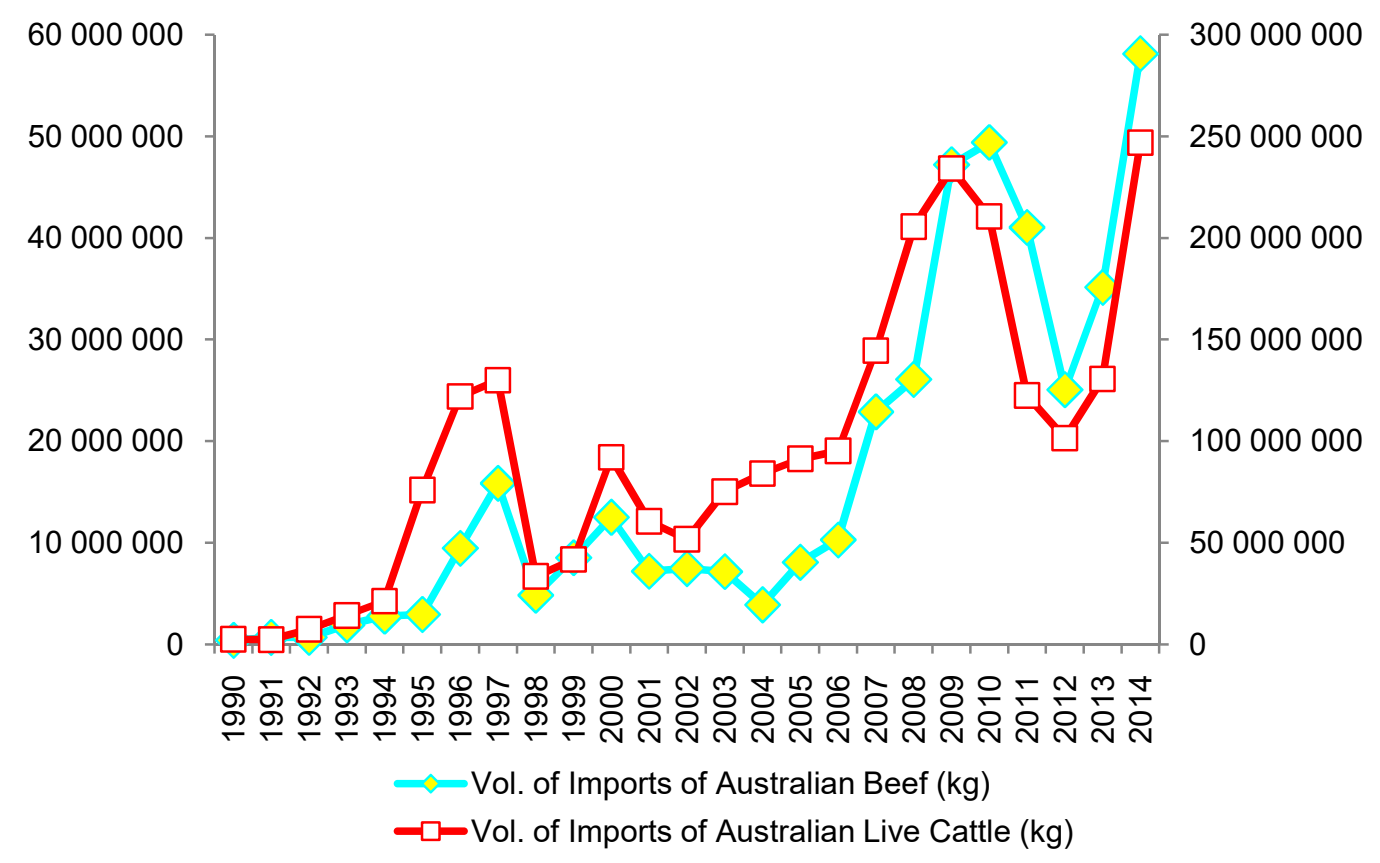

Figure 13 - The Impact of Indonesian Act No. 18 of 2009 on the Development of the Imports of Meat and Live Cattle from Australia in the Period of 1990-2014

The Impact of the Australian Cattle Export Regulations. Shipping by sea or airway will have a negative impact on the quality of beef cattle. Ferguson \& Warner (2008) state that the quality of beef will decrease when the cow is under stress when it is above the sea, especially when it lasts for a long time. On the other hand, there are some concerns that some parties have on the feasibility of handling livestock in Australia.

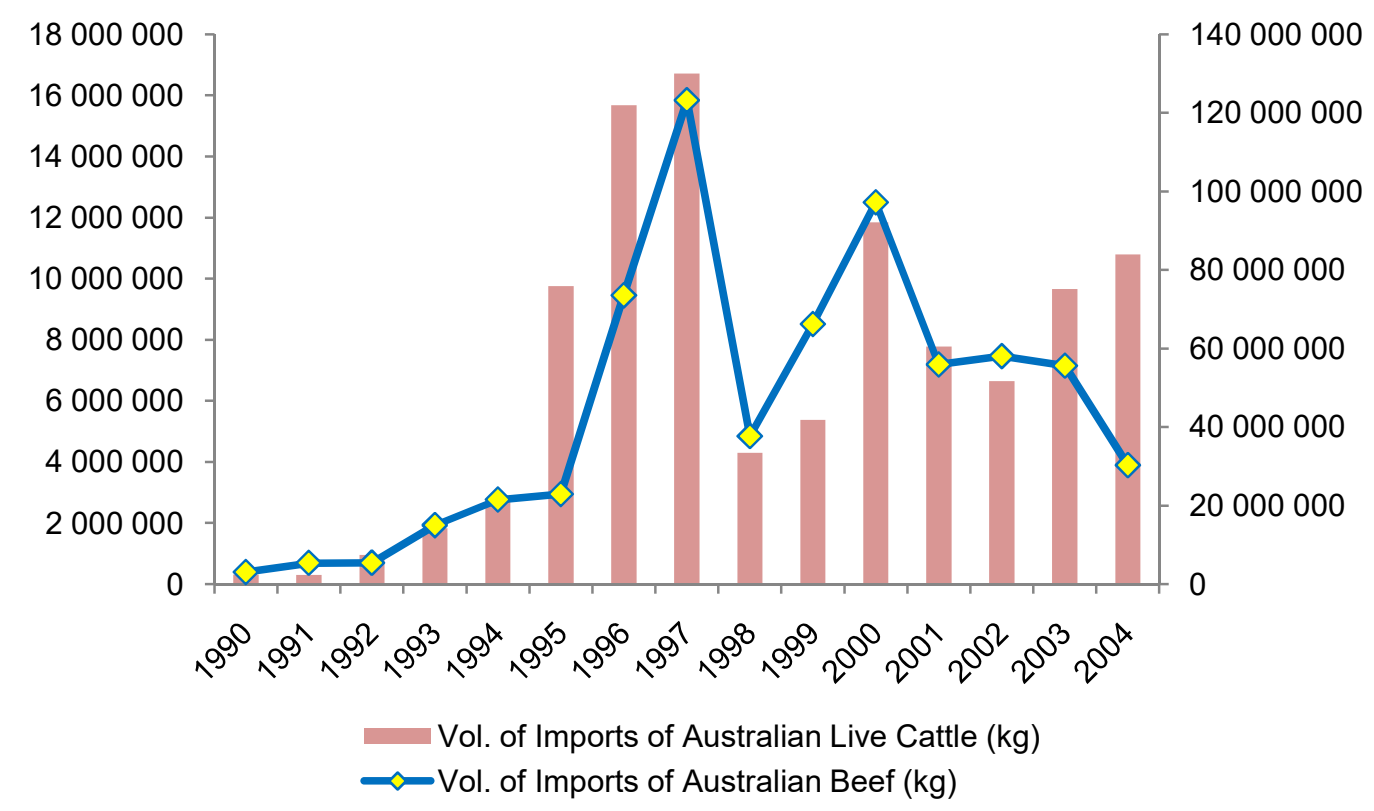

Figure 14 - The Development of the Imports of Beef and Live Cattle from Australia with the Existence of Australian Export Policy 
The animal protection groups, especially the protection of beef cattle, pressure the government to always improve the rules in the management of beef export industry. According to the ABARES report (Martin, Mellor, \& Hooper, 2007), there have been so many demands related to the implementation of governance in the cattle export industry to the Australian government over the past decade. This leads to the implementation of the strict export standards of cattle exports in Australia.

Australia has two key regulatory frameworks that serve as an umbrella in the Australian beef cattle export industry, the Australian Standards for the Export of Livestock (ASEL) and the Exporter Supply Chain Assurance System (ESCAS) (Deards, Leith, et al, 2014). ASEL, as a rule initiated in 2004, will focus more on protecting domestic and cross-island transport, either by sea or airways. The current rules of ASEL include 5 aspects (Deards, Leith, et al, 2014), namely: 1) Early preparation of livestock of beef cattle, from the production sources and the management while in breeding site of the beef cattle; 2) Delivery of export ready beef cattle by road; 3) Management of beef cattle at the listed temporary collection point; 4) Preparation of the ship up to the process of loading of beef cattle on board; and 5) Management of beef cattle on board, both sea vessels and airplane.

While the ESCAS regulation aims to minimize the incidents that conflict with animal welfare standards by ensuring better handling of beef cattle in importing countries. The ESCAS contains 4 main rules, namely: 1) Following OIE rules: following the standards set out in OIE; 2) Control: Having controlled reporting and accountability; 3) Traceability: or effective tracking of the authorities, from producers to consumers; and 4) Audits: or willing to be verified by a qualified independent party.

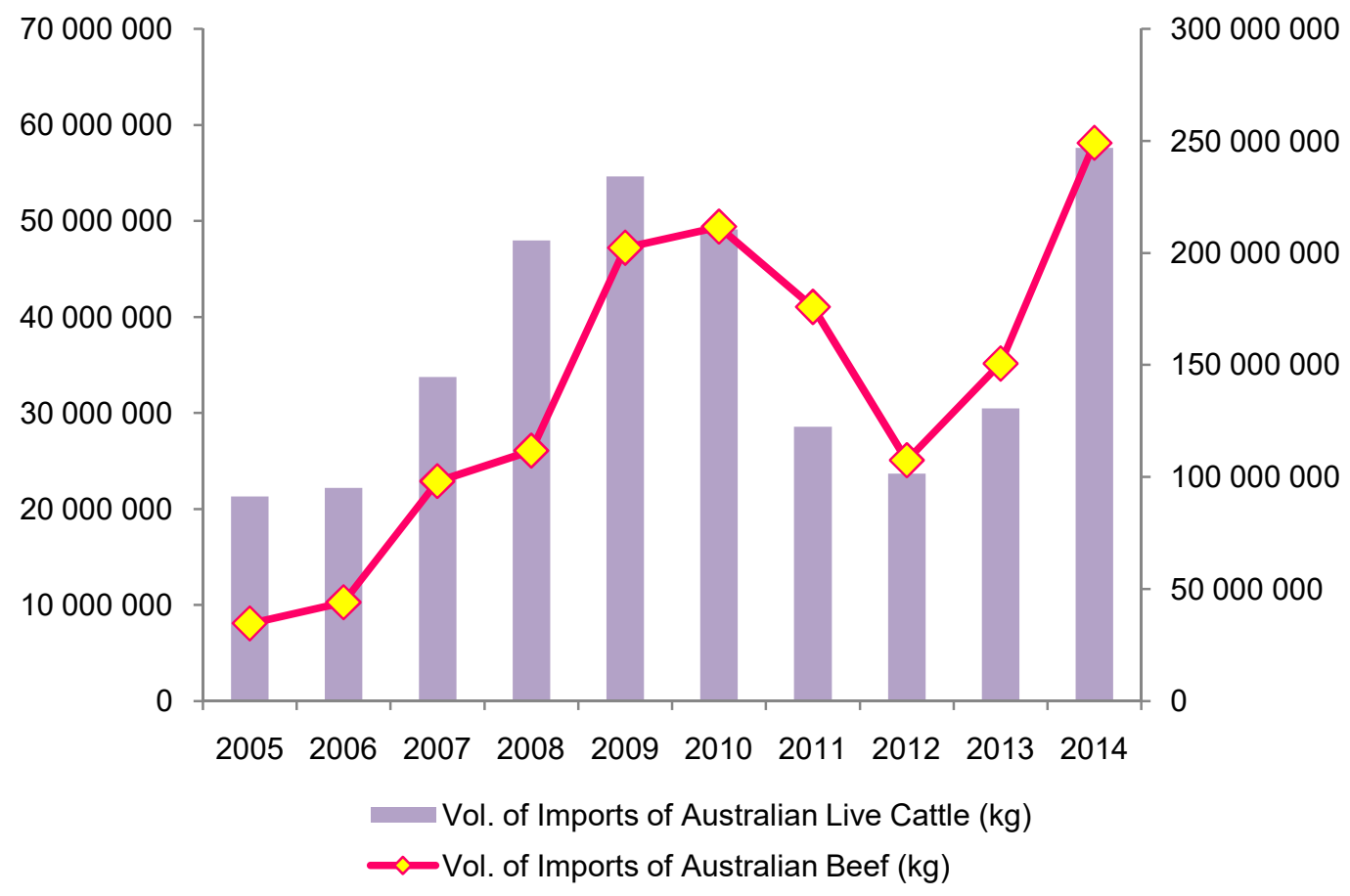

Figure 15 - The Development of the Imports of Beef and Live Cattle from Australia with the Existence of Australian Export Policy

This loss was originally the impact of the unintentional structural violence carried out by the Australian government by setting the policies that were not adaptive to the interests of the Australian beef cattle producers. The implementation of 2 policies, namely An Order under regulation 3 of the Export Control (orders) regulation 1982 - the Export Control (Export of Live-stock to the Republic of Indonesia) Order 2011 and) An Order made under section 17 of the Act - The Australian Meat and Live-stock Industry (Export of Live-stock to the Republic of Indonesia Order 2011) in June 2011 is a policy that is not in favor of local Australian beef producers, especially those who export their beef cattle production to Indonesia. 


\section{CONCLUSION}

The volume of beef imports from Australia has increased enormously over the last 25 years with an average increase of $40.19 \%$ per year. The domestic beef prices during the period of 1990-2014 fluctuated with an increasing trend of an average growth of $7.67 \%$ per year. The development of the domestic beef production in the same period only grew by an average of $3.80 \%$ per year. The domestic beef consumption per capita increased from 0.88 $\mathrm{kg} /$ capita in 1990 to $1.72 \mathrm{~kg} /$ capita in 2014, an average increase of $3.32 \%$ per year. Various policies affecting the imports of beef from Australia are contained in the Indonesian Act No. 18 of 2009 on Animal Husbandry and Animal Health with country-based principle.

\section{REFERENCES}

1. Deards, B; leith, R; Mifsud C; Martin, P and Gleeson, T. 2014. Live expor trade assesment. Report to client prepared for the live animal exports reform taskforce, Departement of Agriculture. ABARES.

2. FAO (2012) June 2016 Food Outlook. Geneva: FAO

3. FAO (2014) May 2014 Food Outlook. Geneva: FAO

4. FAO (2016) June 2016 Food Outlook. Geneva: FAO

5. FAO (2016) October 2016 Food Outlook. Geneva: FAO

6. Ferguson, D.M., and R.D. Warner. 2008. Have we underestimated the impact of preslaughter stress on meat quality in ruminants? Meat Science 80 (2008) page $12-19$.

7. Ilham, N. 2009. The Scarcity of Meat Production: Indications and Its Policy Implications. An Analysis of Agricultural Policy. Journal 7 (1). 43-63.

8. Ilham, N. (2014). An Analysis of the supply and demand of beef in Indonesia. JITV, 19 (3).

9. Instruksi Presiden Republik Indonesia Nomor 2 Tahun 1998 Tentang Perdagangan Antar Daerah Tingkat I dan Daerah Tingkat II/Pulau

10. Martin, P; T .V. Mellor and S. Hooper. 2007. Live Cattle Export Trade Importance to Northen and southern Australian Beef Industries. ABARES.

11. Ministry of Trade of RI. 2014. International Price Statistics 2008- 2013. Downloaded on the $5^{\text {th }}$ of September 2014 from http: //www.kemendag. go.id/id/economic-profile/prices/

12. Ministry of Agriculture of RI (2015). Outlook of Agricultural Commodities: Sub-Subsector of Beef Cattle Husbandry. Center for Agricultural Data and Information System of the Secretariat General of the Ministry of Agriculture.

13. The Regulation of the Minister of Trade No. 24 / M-Dag / Per / 9/2011 On the Provisions on the Import and Export of Animals and Veterinary Products.

14. The Regulation of the Minister of Trade No. 46 / M-Dag / Per / 8/2013 on Provisions on the Import and Export of Animals and Veterinary Products.

15. The Regulation of the Minister of Agriculture Number: 59 / Permentan / HK.060 / 8/2007 About the Guidelines for Accelerating the Achievement of Self-Sufficiency for Beef

16. The Regulation of the Minister of Agriculture Number: 19 / Permentan / OT.140 / 2/2010 On the General Guidelines of the Beef Self-Sufficiency Program 2014.

17. The Regulation of the Minister of Agriculture Number: 50 / Permentan / OT.140 / 9/2011 On the Recommendation on Approval of Import of Carcass, Meat, Offal, and / or Processed Items into Indonesian Regions.

18. Tenrisanna, V., Rahman, M. M., \& Khanam, R. (2016). Beef and offal market in Indonesia-evaluation of import trade policy. Asian Profile, 44 (3), 199-208.

19. Tseuoa T. 2011. Impact of ASEAN Australia and New Zealand Free Trade Agreement on Beef Industry in Indonesia. Thesis. Bogor: Graduate School of Bogor Agricultural University.

20. The Indonesian Act Number 18 of the Year 2009 About Animal Husbandry and Animal Health. 